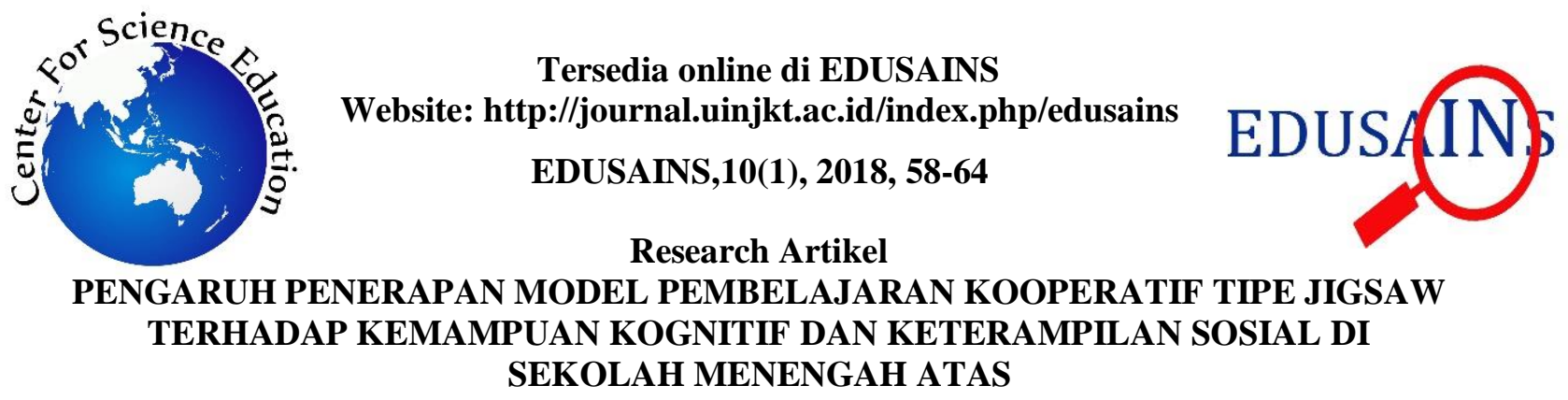

\title{
EFFECT OF APPLICATION OF COOPERATIVE LEARNING MODEL OF JIGSAW TO COGNITIVE ABILITY AND SOCIAL SKILL IN HIGH SCHOOL
}

\author{
Amrina Muthi’ah, Yenny Anwar, Lucia Maria Santoso \\ Universitas Sriwijaya, Palembang, Indonesia \\ amrina_muthiah@yahoo.co.id
}

\begin{abstract}
This study aims to obtain information on the effect of applying jigsaw type cooperative learning model to students cognitive and social skills on excretory system materials in SMA Negeri 15 Palembang. The research method used was Quasi Experimental Design with Nonequivalent Control Group Design. Based on the above data can be conclu

ded that the application of cooperative learning model type jigsaw significantly influence the cognitive abilities and social skills of students on excretory system material in SMA Negeri 15 Palembang. The correlation test results of these two variables have a lower significance of 0.05 (Sig <0.05) was 0.002 and the correlation coefficient value was 0.549 indicating that there was a relationship between the cognitive ability and social skills of students with a positive relationship direction.
\end{abstract}

Keywords: jigsaw type cooperative learning; cognitive ability; social skills; human excretion system

\begin{abstract}
Abstrak
Penelitian ini bertujuan untuk mendapatkan informasi mengenai pengaruh penerapan model pembelajaran kooperatif tipe jigsaw terhadap kemampuan kognitif dan keterampilan sosial siswa pada materi sistem ekskresi di SMA Negeri 15 Palembang. Metode penelitian yang digunakan yaitu Quasi Experimental Design dengan Nonequivalent Control Group Design. Berdasarkan data diatas dapat disimpulkan bahwa penerapan model pembelajaran kooperatif tipe jigsaw berpengaruh signifikan terhadap kemampuan kognitif dan keterampilan sosial siswa pada materi sistem ekskresi di SMA Negeri 15 Palembang. Adapun hasil uji korelasi dua variabel tersebut memiliki signifikansi lebih rendah dari 0,05 (Sig < 0,05) yaitu 0,002 dan nilai koefisien korelasinya yaitu 0,549 yang menunjukkan bahwa terdapat hubungan antara kemampuan kognitif dan keterampilan sosial siswa dengan arah hubungan yang positif.
\end{abstract}

Kata kunci: model pembelajaran kooperatif tipe jigsaw; kemampuan kognitif; keterampilan social; sistem ekskresi manusia.

Permalink/DOI: http://dx.doi.org/10.15408/es.v10i1.7148

\section{PENDAHULUAN}

Pendidikan adalah suatu usaha sadar dan terencana untuk mewujudkan proses pembelajaran dengan suasana belajar yang dapat menjadikan siswa secara aktif mengembangkan potensi dirinya untuk memiliki pengendalian diri, kepribadian, kecerdasan serta keterampilan yang diperlukan dirinya dan masyarakat (UU Nomor 20 Tahun 2003). Melalui pendidikan diharapkan dapat terciptanya sumber daya manusia yang lebih berkualitas lagi baik itu dari segi akademis atau non-akademis (Ulansari dan Bertha, 2012). Oleh karena itu, pemerintah harus terus melakukan pembaharuan dalam dunia pendidikan untuk meningkatkan kualitas pendidikan. Salah satu komponen yang perlu diperhatikan dalam pembaharuan pendidikan, yaitu kualitas pembelajaran. Salah satu kualitas pembelajaran 
yang harus terus ditingkatkan yaitu pada pembelajaran Biologi (Isjoni, 2013).

Pembelajaran biologi selama ini dipandang sebagai mata pelajaran yang sulit oleh siswa, cenderung monoton dan tidak menarik (Sulastri dan Diana, 2009). Selain itu menurut Cimer (2012), ilmu biologi itu mencakup banyak konsepkonsep yang abstrak, didasarkan pada menghafal sehingga membuat siswa kesulitan untuk belajar. Salah satu materi pembelajaran biologi yang dianggap cukup sulit oleh siswa yaitu materi sistem ekskresi. Materi sistem ekskresi ini bersifat abstrak yang berarti tidak dapat dilihat langsung oleh siswa dan materi ekskresi juga dianggap sulit karena banyak materi teori dan konsep sehingga membutuhkan pemahaman dan pengetahuan yang baik (Susanto, 2014). Kesulitan belajar yang dialami oleh siswa juga disebabkan oleh cara mengajar guru yang masih bersifat konvensional. Apabila guru tidak melakukan perannya dengan benar maka dapat berdampak pada tidak tercapainya tujuan pembelajaran yang berakibat pada rendahnya hasil kemampuan kognitif siswa karena siswa kurang mampu memberdayakan potensi yang ada di dalam dirinya.

Proses pembelajaran konvensional ini kurang melibatkan siswa dalam proses pembelajaran sehingga siswa kurang memiliki keterampilan sosial yang baik. Selama ini sekolah hanya menekankan pada pencapaian siswa dari segi kognitif saja dan tidak terlalu memperhatikan perkembangan keterampilan sosial siswa yang mengakibatkan siswa mengalami kecemasan sosial, kesepian, dan berdampak pada rendahnya nilai akademis siswa (Purwanti, 2014). Sejalan dengan itu menurut Anwar (2010) saat ini masih banyak ditemukannya siswa yang kurang aktif, siswa yang tergolong cerdas cenderung tidak mau membantu temannya untuk memahami materi pelajaran, siswa yang masih belum mengerti tidak mau bertanya kepada teman yang sudah mengerti dikarenakan gengsi ataupun malu, hal ini karena proses pembelajaran hanya menekankan pada kemampuan kognitif siswa saja. Berdasarkan beberapa penelitian yang telah dilakukan, misalnya penelitian Fadliyani (2014), Pradipta (2013), Awal (2013), juga menyatakan bahwa proses pembelajaran yang masih bersifat konvensional ini menyebabkan rendahnya kemampuan kognitif siswa dan kurang berkembangnya keterampilan sosial siswa. Proses pembelajaran seperti inilah yang dapat mengakibatkan kurang optimalnya kualitas pembelajaran sehingga perlu dilakukannya peningkatan kualitas pembelajaran. Peningkatan kualitas pembelajaran ini dapat dilakukan dengan berbagai cara, salah satunya yaitu dengan menerapkan model pembelajaran yang efektif di kelas dan lebih memberdayakan potensi siswa (Isjoni, 2013).

Banyak model pembelajaran yang dapat digunakan untuk merubah proses pembelajaran yang bersifat konvensional. Salah satu model pembelajaran yang dapat digunakan adalah model pembelajaran kooperatif tipe jigsaw. Model pembelajaran kooperatif tipe jigsaw merupakan salah satu tipe pembelajaran melalui penggunaan kelompok kecil yang dapat membantu dan mendorong siswa untuk aktif dan saling membantu dalam menguasai materi pelajaran untuk mencapai hasil belajar yang maksimal (Isjoni, 2013). Selain itu model pembelajaran kooperatif tipe jigsaw juga memberikan pengalaman belajar yang lebih maksimal, baik pengalaman belajar secara inividu ataupu secara kelompok. Pembelajaran kooperatif tipe jigsaw ini mengambil pola cara bekerja sebuah gergaji (zigzag), yaitu siswa melakukan suatu kegiatan belajar dengan cara bekerja sama dengan siswa lainnya untuk mencapai tujuan bersama (Rusman, 2014). Model ini sesuai dengan materi ekskresi yang memiliki beberapa bagian materi yang dapat dibagi-bagi karena pada model pembelajaran kooperatif tipe jigsaw ini terdiri dari dua jenis kelompok yaitu kelompok asal dan kelompok ahli. Setiap siswa di dalam kelompok asal tersebut akan mendapat satu bagian materi yang berbeda dan mendiskusikannya di dalam kelompok ahli. Setelah itu setiap siswa akan menjelaskan materi yang telah didiskusikan tersebut di dalam kelompok asal. Hal ini dilakukan agar siswa lebih mudah untuk mempelajari materi tersebut dan penguasaan terhadap materi ekskresi dapat merata dan dicapai dalam waktu yang singkat (Susanto, 2014).

Tujuan penting terakhir dalam proses pembelajaran dengan menggunakan model pembelajaran kooperatif tipe jigsaw ini yaitu mengajarkan siswa mengenai keterampilan kerja sama dan kolaborasi yang nantinya akan sangat 
bermanfaat dalam kehidupan bermasyarakat (Asmani, 2016). Selain itu keterampilan sosial ini sangat diperlukan dalam proses pembelajaran agar siswa dapat bekerja sama dan berkomunikasi dengan baik dengan temannya. Berdasarkan beberapa penelitian yang telah dilakukan seperti penelitian yang dilakukan oleh Pradipta (2013) dan Fadliyani (2014) menunjukkan bahwa siswa yang terlibat di dalam model pembelajaran kooperatif tipe jigsaw ini memperoleh kemampuan kognitif yang baik, mempunyai sikap yang lebih baik dan lebih positif terhadap pembelajaran, di samping itu keterampilan sosial siswa juga menjadi lebih baik, misalnya siswa saling menghargai perbedaan dan pendapat orang lain, mampu bekerja sama di dalam sebuah kelompok, berinteraksi dan berkomunikasi dengan baik.

Dengan demikian, diharapkan dengan menerapkan model pembelajaran kooperatif tipe jigsaw ini diruang lingkup SMA Negeri 15 Palembang dapat membantu siswa untuk lebih meningkatkan dan memperbaiki kemampuan kognitif dan melatih keterampilan sosialnya didalam lingkungan sekolah maupun lingkungan masyarakat.

\section{METODE}

Desain penelitian yang digunakan adalah Quasi Experimental Design dengan bentuk desain Nonequivalent Control Group Design. Bentuk desain ini terdapat tes awal sebelum diberi perlakuan dan tes akhir setelah diberi perlakuan. Penelitian dilaksanakan di SMA Negeri 15 Palembang dengan melibatkan dua kelas yang berjumlah 53 orang.

Teknik pengumpulan data dalam penelitian ini berupa tes tertulis dan lembar observasi. Tes tertulis yang terdiri dari 40 soal pilihan ganda. Lembar observasi dilakukan dengan cara mengamati langsung oleh observer selama proses pembelajaran berlangsung.

Analisis hasil kemampuan kognitif dibantu dengan menggunakan bantuan program Statiscal Program for Social Science 22 (SPSS 22). Uji normalitas menggunakan uji Shapiro-Wilk kemudian dilanjutkan dengan uji-t menggunakan Independent-sample t-test. Menurut Hake (1998) dikutip Meltzer (2002), peningkatan kemampuan berpikir tingkat tinggi menggunakan nilai gain yang ternormalisasi (n-gain) dengan menggunakan rumus sebagai berikut :

$$
\mathrm{n}-\text { gain }=\frac{\text { tes akhir }- \text { tes awal }}{\text { skor ideal }- \text { tes awal }}
$$

Indeks kategori n-gain dikelompokkan menjadi tiga kategori, yaitu tinggi ( $g \geq 0,7)$, sedang $(0,3<$ $\mathrm{g}<0,7)$, dan rendah $(\mathrm{g} \leq 0,3)$.

Analisis lembar observasi keterampilan sosial dihitung berdasarkan indikator dan deskriptor yang bersesuaian dengan aspek yang diamati yaitu aspek kerjasama dan kemampuan komunikasi. Adapun menurut Supardi (2015) cara menghitungnya dengan menggunakan rumus sebagai berikut :

$$
\text { Nilai siswa }=\frac{\text { Jumlah skor yang diperoleh }}{\text { Jumlah skor ideal seluruh item }} \times 100
$$

Kemudian data tersebut diuji normalitas dan juga diuji hipotesis dengan menggunakan bantuan program SPSS 22.

Selain itu juga dilakukan analisis koefisien korelasi product moment dengan menggunakan bantuan program SPSS 22 dengan menggunakan uji Pearson Correlation. Angka korelasi ini berkisar antara $-1 \mathrm{~s} / \mathrm{d}+1$. Semakin mendekati 1 maka korelasinya akan semakin sempurna. Sementara adanya tanda negatif/positif tersebut mengindikasikan suatu hubungan, apabila tandanya positif menandakan bahwa pola hubungannya searah. Uji ini dilakukan untuk melihat ada tidaknya hubungan antara variabel kemampuan kognitif dan keterampilan sosial yang dimiliki siswa.

\section{HASIL DAN PEMBAHASAN}

Sebelum Proses Pembelajaran Dengan Menggunakan Model Pembelajaran Kooperatig Tipe Jigsaw Dimulai, Siswa Terlebih Dahulu Diberi Tes Awal Untuk Melihat Sejauh Mana Kemampuan Dasar Yang Dimiliki Oleh Siswa, Kemudian Setelah Diberi Perlakuan Maka Diberikan Lagi Tes Akhir Untuk Melihat Sejauh Mana Kemampuan Kognitif Yang Diperoleh Siswa Setelah Diberi Perlakuan. Persentase Hasil Analisis Kemampuan Kognitif Siswa Dapat Dilihat Pada Tabel1. 
Tabel 1 Hasil Analisis Kemampuan Kognitif Siswa

\begin{tabular}{|c|c|c|c|c|c|c|c|}
\hline \multirow[b]{2}{*}{ Jenis Tes } & \multirow[b]{2}{*}{ Kelas } & \multicolumn{5}{|c|}{ Kategori Kemampuan Kognitif (\%) } & \multirow{2}{*}{$\begin{array}{c}\text { Ketuntasan } \\
(\%)\end{array}$} \\
\hline & & $\begin{array}{c}\text { Baik } \\
\text { Sekali }\end{array}$ & Baik & Cukup & Kurang & $\begin{array}{c}\text { Sangat } \\
\text { Kurang }\end{array}$ & \\
\hline \multirow{2}{*}{ Tes Awal } & Eksperimen & - & - & 75 & 7,14 & 17.86 & - \\
\hline & Kontrol & - & - & 100 & - & - & - \\
\hline Tes Akhir & $\begin{array}{c}\text { Eksperimen } \\
\text { Kontrol }\end{array}$ & 32,14 & $\begin{array}{c}67,86 \\
84\end{array}$ & - & - & - & $\begin{array}{c}89.29 \\
28\end{array}$ \\
\hline
\end{tabular}

Tabel 2 Hasil Uji Normalitas Data Kemampuan Kognitif

\begin{tabular}{cccccc}
\hline \multirow{2}{*}{ Jenis Tes } & \multirow{2}{*}{ Kelas } & \multicolumn{3}{c}{ Shapiro-Wilk } & \multirow{2}{*}{ Interpretasi } \\
\cline { 3 - 5 } & & Statistic & Df & Sig. & \\
\hline \multirow{2}{*}{ Tes Awal } & Eksperimen & 0,928 & 28 & 0,055 & Normal \\
& Kontrol & 0,961 & 25 & 0,441 & Normal \\
\multirow{2}{*}{ Tes Akhir } & Eksperimen & 0,938 & 28 & 0,100 & Normal \\
& Kontrol & 0,939 & 25 & 0,141 & Normal \\
\hline
\end{tabular}

Dari Hasil Yang Disajikan Pada Tabel 1, Dapat Dilihat Bahwa Pada Tes Awal Kelas Eksperimen Dan Kelas Kontrol Tidak Memperoleh Persentase Pada Kategori Sangat Baik, Kedua Kelas Tersebut Hanya Memperoleh Persentase Pada Kategori Cukup Yaitu Kelas Eksperimen Sebesar 100\% Dan Untuk Kelas Kontrol Sebesar 75\%. Sedangkan Pada Tes Akhir Kelas Eksperimen Memperoleh Persentase Pada Kategori Sangat Baik Sebesar 32,14\% Dan Kelas Kontrol Tidak Memperoleh Persentase Pada Kategori Sangat Baik. Lalu Untuk Tingkat Ketuntasan, Kelas Eksperimen Memiliki Ketuntasan Yang Sangat Baik Yaitu 89,29\%, Sedangkan Pada Kelas Kontrol Hanya 28\%. Jika Dilihat Dari Persentase Ketuntasan Siswa Pada Kelas Eksperimen Maka Penggunaan Model Pembelajaran Kooperatif Tipe Jigsaw Dalam Proses Pembelajaran Dapat Menjadi Pilihan Alternatif Yang Digunakan Guru Untuk Meningkatkan Kemampuan Kognitif Dan Meningkatkan Persentase Ketuntasan Siswa Pada Pembelajaran Biologi. Selanjutnya Dilakukan Uji Normalitas Data Dan Uji Hipotesis Yang Hasilnya Dapat Dilihat Pada Tabel 2 .

Berdasarakan Tabel 2. Dapat Menunjukkan Nilai Signifikansi Dari Tes Awal Dan Tes Akhir Kemampuan Kognitif Siswa Lebih Besar Dari 0,05 (Sig > 0,05) Sehingga Dapat Dikatakan Bahwa Data Tes Awal Dan Tes Akhir Kemampuan Kognitif Pada Kedua Kelas Tersebut Terdistribusi Secara Normal. Data Yang Terdistribusi Secara Normal Ini Dapat Dilanjutkan Ke Uji-T.
Uji-T Dilakukan Dengan Menggunakan Bantuan Program Aplikasi SPSS 22 Dengan Menggunakan Uji Independent Sample T-Test. Uji Ini Dilakukan Dengan Cara Membandingkan Nilai Gain Dari Kelas Eksperimen Dan Kelas Kontrol Dengan Kriteria Ho Ditolak Jika $\mathrm{T}_{\text {hitung }}>\mathrm{T}_{\text {tabel }}$ Pada Taraf Signifikansi 5\% $(\mathrm{A}=0,05)$ Dan $(\mathrm{Dk})=(\mathrm{N} 1+$ N2) - 2. Dari Hasil Analisis Uji-T Ini Menunjukkan Bahwa Nilai $\mathrm{T}_{\text {hitung }}>\mathrm{T}_{\text {tabel }}$ Yaitu 5,573> 2,008 Sehingga Ho Ditolak Dan Ha Diterima. Hal Ini Menunjukkan Bahwa Model Pembelajaran Kooperatif Tipe Jigsaw Berpengaruh Signifikan Terhadap Kemampuan Kognitif Siswa Pada Materi Sistem Ekskresi Di SMA Negeri 15 Palembang.

Peningkatan Kemampuan Kognitif Ini Juga Didukung Dengan Adanya Lembar Observasi Mengenai Keterampilan Sosial Siswa. Data Keterampilan Sosial Siswa Didapatkan Dengan Cara Melakukan Pengamatan Selama Proses Pembelajaran Berlangsung. Adapun Hasil Dari Data Keterampilan Sosial Siswa Dapat Dilihat Pada Tabel 3.

Berdasarkan Tabel 3 Dapat Dilihat Bahwa Kelas Eksperimen Yang Menerapkan Model Pembelajaran Kooperatif Tipe Jigsaw Memiliki Keterampilan Sosial Yang Baik Dengan Melihat Perbedaan Persentase Untuk Kategori Sangat Baik Seluruh Siswa Kelas Eksperimen Sudah Mencakup Semua Indikator Dengan Persentase Paling Tinggi Yaitu 100\% Pada Indikator 1, 2 Dan 7 Sedangkan Untuk Siswa Kelas Kontrol Hanya Mencakup 7 Indikator Saja Dengan Persentase Paling Tinggi 
Yaitu 72\% Pada Indikator Ke 3. Lalu Dilihat Dari Hasil Rata-Rata Menunjukkan Bahwa Kelas Eksperimen Memiliki Persentase Sebesar 71,43\% Pada Kategori Baik Dan Kelas Kontrol Memiliki Persentase Sebesar 35\% Pada Kategori Baik,
Sedangkan Untuk Kategori Lainnya Persentase Kelas Kontrol Lebih Besar Dibandingkan Kelas Kontrol. Adapun Hasil Data Keterampilan Sosial Ini Juga Dilakukan Uji Normalitas Data Dan Uji Hipotesis Yang Dapat Dilihat Pada Tabel 4.

Tabel 3. Persentase Kategori Keterampilan Sosial Siswa

\begin{tabular}{|c|c|c|c|c|c|c|c|c|c|c|}
\hline \multirow{3}{*}{ Indikator } & \multicolumn{10}{|c|}{ Persentase Kategori Keterampilan Sosial (\%) } \\
\hline & \multicolumn{2}{|c|}{ SB } & \multicolumn{2}{|c|}{$\mathbf{B}$} & \multicolumn{2}{|c|}{$\mathrm{C}$} & \multicolumn{2}{|c|}{$\mathbf{K}$} & \multicolumn{2}{|c|}{ SK } \\
\hline & Eks & $\mathbf{K}$ & Eks & $\mathbf{K}$ & Eks & $\mathbf{K}$ & Eks & $\mathbf{K}$ & Eks & $\mathbf{K}$ \\
\hline $\begin{array}{l}\text { Sungguh-Sungguh } \\
\text { Mengerjakan Tugas } \\
\text { Kelompok }\end{array}$ & 100 & 68 & - & 20 & - & 12 & - & - & - & - \\
\hline $\begin{array}{l}\text { Menghormati Perbedaan } \\
\text { Individu }\end{array}$ & 100 & 40 & - & 24 & - & 16 & - & 16 & - & 4 \\
\hline $\begin{array}{l}\text { Berinteraksi Dalam } \\
\text { Kelompok }\end{array}$ & 96,43 & 72 & 3,57 & 24 & - & 4 & - & - & - & - \\
\hline $\begin{array}{l}\text { Menghargai Kelompok } \\
\text { Lain }\end{array}$ & 96,43 & 28 & 3,57 & 36 & - & 16 & - & 20 & - & - \\
\hline $\begin{array}{l}\text { Menyampaikan Materi } \\
\text { Dengan Bahasa Yang } \\
\text { Santun Dan Dapat Di } \\
\text { Pahami Oleh Guru/Siswa } \\
\text { Lain }\end{array}$ & 42,86 & 8 & 25 & 8 & 25 & 20 & 7,14 & 40 & - & 24 \\
\hline $\begin{array}{l}\text { Menyampaikan } \\
\text { Sanggahan Dan Pendapat } \\
\text { Dengan Baik }\end{array}$ & 14,29 & - & 28,57 & 8 & 25 & 16 & 10,71 & 20 & 21,43 & 56 \\
\hline $\begin{array}{l}\text { Menerima Materi Yang } \\
\text { Disampaikan Oleh } \\
\text { Guru/Teman Sekelas } \\
\text { Dengan Serius }\end{array}$ & 100 & 48 & - & 20 & - & 28 & - & 4 & - & - \\
\hline $\begin{array}{l}\text { Menanyakan Kepada } \\
\text { Guru Terhadap Materi } \\
\text { Pembelajaran Yang } \\
\text { Belum Dipahami }\end{array}$ & 21,43 & 16 & 25 & 8 & 35,71 & 16 & 3,57 & 24 & 14,29 & 36 \\
\hline Rata-Rata & 71,43 & 35 & 10,71 & 18,5 & 10,71 & 16 & 2,68 & 15,5 & 4,47 & 15 \\
\hline
\end{tabular}

Tabel 4 Hasil Uji Normalitas Data Keterampilan Sosial

\begin{tabular}{ccccc}
\hline \multirow{2}{*}{ Kelas } & \multicolumn{3}{c}{ Shapiro-Wilk } & \multirow{2}{*}{ Interpretasi } \\
\cline { 2 - 4 } & Statistic & Df & Sig. & \\
\hline Eksperimen & 0,941 & 28 & 0,119 & Normal \\
Kontrol & 0,944 & 25 & 0,184 & Normal \\
\hline
\end{tabular}

Tabel 5 Hasil Uji Korelasi Kemampuan Kognitif Dan Keterampilan Sosial Siswa

\begin{tabular}{|c|c|c|c|c|}
\hline \multicolumn{2}{|c|}{ Jenis Tes } & Tes Akhir & $\begin{array}{c}\text { Keterampilan } \\
\text { Sosial Siswa }\end{array}$ & $\begin{array}{c}\text { Interpretasi } \\
\text { Korelasi }\end{array}$ \\
\hline \multirow{4}{*}{$\begin{array}{c}\text { Keterampilan Sosial } \\
\text { Siswa }\end{array}$} & $\begin{array}{c}\text { Pearson } \\
\text { Correlation }\end{array}$ & 1 & $0,549^{*}$ & \multirow{4}{*}{ Sedang } \\
\hline & Sig. (2-Tailed) & & 0,002 & \\
\hline & $\begin{array}{c}\text { Pearson } \\
\text { Correlation }\end{array}$ & $0,549^{*}$ & 1 & \\
\hline & Sig. (2-Tailed) & 0,002 & & \\
\hline
\end{tabular}

Tabel 4 Menunjukkan Nilai Signifikansi Data Keterampilan Sosial Siswa Lebih Besar Dari 0,05 (Sig > 0,05) Sehingga Dapat Disimpulkan Bahwa
Data Keterampilan Sosial Siswa Pada Kedua Kelas Tersebut Terdistribusi Secara Normal. Data Yang 
Terdistribusi Secara Normal Ini Dapat Dilanjutkan Ke Uji-T.

Uji-T Ini Dilakukan Dengan Menggunakan Bantuan Program Aplikasi SPSS 22 Dengan Menggunakan Uji Independent Sample T-Test. Uji Ini Dilakukan Dengan Membandingkan Nilai RataRata Keterampilan Sosial Siswa Kelas Eksperimen Dan Kelas Kontrol Dengan Kriteria Ho Ditolak Jika $\mathrm{T}_{\text {hitung }}>\mathrm{T}_{\text {tabel }}$ Pada Taraf Signifikansi 5\% $(\mathrm{A}=0,05)$ Dan $(\mathrm{Dk})=(\mathrm{N} 1+\mathrm{N} 2)-2$. Hasil Analisis Uji Hipotesis Ini Menunjukkan Bahwa Nilai $\mathrm{T}_{\text {hitung }}>$ $\mathrm{T}_{\text {tabel }}$ Yaitu 9,490 $>2,008$ Sehingga Dapat Disimpulkan Bahwa Model Pembelajaran Kooperatif Tipe Jigsaw Berpengaruh Signifikan Terhadap Keterampilan Sosial Siswa Pada Materi Sistem Ekskresi Di SMA Negeri 15 Palembang.

Meningkatnya Nilai Kemampuan Kognititf Siswa Ternyata Dipengaruhi Juga Oleh Adanya Keterampilan Sosial Yang Dimiliki Oleh Siswa. Hal Ini Dapat Diketahui Melalui Uji Korelasi Yang Telah Dilakukan. Adapun Hasil Dari Uji Korelasi Dapat Dilihat Pada Tabel 5.

Tabel 5 Menunjukkan Bahwa Hasil Uji Korelasi Data Tersebut Memiliki Signifikansi Lebih Rendah Dari 0,05 (Sig < 0,05) Yaitu 0,002. Hal Ini Menunjukkan Bahwa Terdapat Korelasi Antara Kemampuan Kognitif Dan Keterampilan Sosial Siswa. Nilai Koefisien Korelasi Kemampuan Kognitif Dan Keterampilan Sosial Siswa Adalah 0,549 Yang Berarti Hubungan Antara Kemampuan Kognitif Dan Keterampilan Sosial Siswa Berada Pada Kategori Sedang. Koefisien Tersebut Bernilai Positif Yang Menunjukkan Bahwa Arah Hubungan Yang Positif Yaitu Semakin Tinggi Nilai Tes Keterampilan Sosial Siswa Maka Semakin Tinggi Pula Nilai Tes Kemampuan Kognitifnya Dan Begitu Juga Sebaliknya.

Berdasarkan Hasil Uraian Di Atas, Terjadi Peningkatan Kemampuan Kognitif Dan Keterampilan Sosial Siswa Dengan Menggunakan Model Kooperatif Tipe Jigsaw. Model Kooperatif Tipe Jigsaw Sendiri Merupakan Model Pembelajaran Yang Mendorong Siswa Untuk Lebih Aktif Dan Saling Membantu Dalam Menguasai Materi Pelajaran Agar Dapat Meningkatkan Hasil Belajar Yang Lebih Maksimal Lagi (Isjoni, 2013). Selama Proses Pembelajaran Menggunakan Model
Pembelajaran Kooperatif Tipe Jigsaw Berlangsung Terutama Saat Diskusi Kelompok Ahli Dan Diskusi Kelompok Asal, Siswa Dapat Melatih Dirinya Untuk Mampu Bekerja Sama Dengan Teman Satu Kelompoknya, Saling Memiliki Ketergantungan Positif, Dan Siswa Juga Harus Bertanggung Dengan Tugas Yang Didapatkannya. Selain Itu Juga Siswa Dapat Memperkuat Kembali Pengetahuan Yang Telah Ia Miliki Dengan Saling Membantu Apabila Ada Temannya Yang Masih Belum Memahami Materi Yang Diajarkan. Hal Seperti Ini Sangat Diperlukan Untuk Mencapai Tujuan Bersama Dan Untuk Meningkatkan Hasil Belajar Siswa Dari Segi Kemampuan Kognitifnya.

Selain Dapat Meningkatkan Kemampuan Kognitif Siswa, Penerapan Model Pembelajaran Kooperatif Tipe Jigsaw Ini Juga Dapat Meningkatkan Keterampilan Sosial Siswa. Menurut Susanto (2014) Mengatakan Bahwa Model Pembelajaran Kooperatif Tipe Jigsaw Ini Dapat Melatih Siswa Untuk Mengembangkan Sikap Saling Kerja Sama, Saling Menghargai, Berinteraksi Dan Berkomunikasi Dengan Baik, Serta Mampu Bersosialisasi Dengan Teman Satu Kelompok Maupun Teman Satu Kelasnya. Hal Ini Dapat Dilihat Bahwa Siswa Telah Dapat Berkomunikasi Dengan Sesama Temannya, Saling Membantu Saat Mengerjakan Tugas, Mengajak Temannya Untuk Bekerja Sama, Dan Menghargai Saat Ada Temannya Yang Sedang Menyampaikan Pendapat. Hasil Ini Juga Sejalan Dengan Hasil Dari Penelitian Yang Dilakukan Oleh Pradipta (2013) Yang Menyatakan Bahwa Peningkatan Keterampilan Sosial Siswa Dapat Terlihat Dari Kemampuan Siswa Dalam Menjaga Kelompoknya, Mampu Memberikan Kontribusi Untuk Kelompoknya Yang Ditunjukkan Dengan Cara Membagi Tugas Untuk Mencari Informasi Dan Saling Mengingatkan Saat Temannya Ramai Sendiri.

Meningkatnya Kemampuan Kognitif Ini Ternyata Dipengaruhi Juga Oleh Keterampilan Sosial Siswa, Hal Ini Dapat Dilihat Dari Hasil Uji Korelasi. Para Siswa Yang Memiliki Kemampuan Kognitif Yang Baik Tidak Terlepas Dari Bagaimana Keterampilan Sosialnya Dalam Hal Berinteraksi Dengan Sesama Temannya Dan Juga Dengan Guru. Menurut Muslich (2009) Dikutip 
Wahyuni (2011) Bahwa Dengan Adanya Proses Interaksi Antar Siswa Memungkinkan Mereka Untuk Saling Membantu Dalam Memperbaiki Kesalahan, Memperbanyak Wawasan, Dan Meningkatkan Keterampilan Sosial Seperti Kerja Sama Dan Komunikasi.

\section{PENUTUP}

Berdasarkan uraian di atas, maka dapat disimpulkan bahwa kegiatan pembelajaran dengan menggunakan model pembelajaran kooperatif tipe jigsaw berpengaruh signifikan terhadap peningkatan kemampuan kognitif dan keterampilan sosial siswa. Adapun kemampuan kognitif dan keterampilan sosial siswa ini juga saling memiliki hubungan korelasi dengan kategori sedang dan arah yang positif.

Adapun disarankan untuk penelitian selanjutnya agar lebih memperhatikan lagi penggunaan waktu dalam menerapkan model pembelajaran kooperatif tipe jigsaw.

\section{DAFTAR PUSTAKA}

Anwar, Y. (2010). Effectiveness of Cooperative Learning Model Type STAD and TPS Against the Results of Student Learners. Proceeding Seminar Internasional. Bandung.

Asmani, J.M. (2016). Tips EfektifCooperative Learning. Yogyakarta:DIVA Press.

Awal, R., dan Masparingga. (2013).Penerapan Model Pembelajaran Kooperatif Tipe Jigsaw Untuk Meningkatkan Hasil Belajar Siswa Kelas XI IPA SMA Nurul Falah Pekanbaru. Jurnal, 04 (01): 54-62.

Cimer, A. (2012). What makes biologylearning difficult and effective: Students' views. Educational Research and Reviews, 7 (3): 61-71.

Fadliyani, $d k k$. (2014). PembelajaranKooperatif Tipe Jigsaw Pada Konsep Sistem Pencernaan Makanan Manusia terhadap Hasil Belajar Siswa SMA Negeri 1 Sakti Kabupaten Pidie. Jurnal Biotik, 2 (1): 1-76.

Isjoni. (2013). Pembelajaran Kooperatif Meningkatkan Kecerdasan Komunikasi Antar Peserta Didik. Yogyakarta: Pustaka Belajar.
Meltzer, D.E. (2012). NormaliizedLearning Gain Akey Measure of Student Learning, Departement of Phsics and Astronomy: Lowa State University.

Pradipta, A.P. (2013). Penerapan Pembelajaran Jigsaw Guna Meningkatkan Penguasaan Konsep dan Keterampilan Sosial Siswa SMA. Jurnal Matematika dan Sains.

Purwanti, E., $d k k$. (2014). Pengembangan Instrumen Keterampilan Sosial Berbasis Observasi dan Sosiometri dalam Pembelajaran IPS. Artikel Penelitian. Lampung.

Rusman. (2014). Model-Model Pembelajaran Mengembangkan Profesionalisme Guru. Jakarta: PT RajaGrafindo.

Sulastri, Y., dan Diana, R. (2009). Pengaruh Penggunaan Pembelajaran Kooperatif Tipe Jigsaw dalam pembelajaran Biologi di SMPN 2 Cimalaka. Jurnal Pengajaran MIPA, 13(1): 15-21.

Supardi. (2015). Penilaian Autentik Pembelajaran Afektif, Kognitif, dan Psikomotorik (Konsep dan Aplikasi). Jakarta: Rajawali Pers.

Susanto, R.D. (2014). Evaluasi Implementasi Model Pembelajaran Kooperatif Tipe Jigsaw Untuk Mata Pelajaran Biologi pada Kelas XI Di SMA Negeri 1 Jombang. Jurnal, 01 (01).

Ulansari, I., dan Bertha, Y. (2012).Keterampilan Sosial Siswa Melalui Pembelajaran Kooperatif Tipe STAD pada Materi Pokok Larutan Penyangga Di SMAN 1 Sumberrejo Bojonegoro. Unesa Journal of Chemical Education, 01(01): 136-144.

UU Nomor 20 tahun 2003 tentang Sistem Pendidikan Pasal 1

Wahyuni, M.R. (2011). Pengaruh Penerapan Model Pembelajaran Kooperatif Tipe Jigsaw Terhadap Kecakapan Komunikasi dan Hasil Belajar Siswa pada Mata Pelajaran Biologi di SMA Negeri 5 Palembang. Skripsi. Palembang: Universitas Sriwijaya. 